\title{
Effect of various surfactants and their concentration on controlled release of captopril from polymeric matrices
}

\author{
ALI NOKHODCHI ${ }^{1,2 *}$ \\ DAVOUD HASSAN-ZADEH ${ }^{2}$ \\ FARNAZ MONAJJEM-ZADEH ${ }^{2}$ \\ NITA TAGHI-ZADEH \\ ${ }^{1}$ Medway School of Pharmacy \\ The University of Kent and Greenwich \\ Central Av., Chatham Maritime \\ ME4 4TB Kent, UK \\ ${ }^{2}$ Drug Applied Research Center \\ and Faculty of Pharmacy Tabriz \\ University of Medical Sciences \\ Tabriz, Iran
}

\begin{abstract}
Various methods are available to formulate water soluble drugs into sustained release dosage forms by retarding the dissolution rate. One of the methods used to control drug release and thereby prolong therapeutic activity is to use hydrophilic and lipophilic polymers. In this study, the effects of various polymers such as hydroxypropyl methylcellulose (HPMC), ethylcellulose (EC) and sodium carboxymethylcellulose (CMC) and surfactants (sodium lauryl sulphate, cetyltrimethylammonium bromide and Arlacel 60) on the release rate of captopril were investigated. The results showed that an increase in the amount of HPMC K15M resulted in reduction of the release rate of captopril from these matrices. When HPMC was partly replaced by $\mathrm{NaCMC}$ (the ratio of $\mathrm{HPMC} / \mathrm{NaCMC}$ was 5:1), the release rate of the drug significantly decreased. However, there was no significant difference in release rate of captopril from matrices produced with ratios of 5:1 and 2:1 of HPMC/NaCMC. The presence of lactose in matrices containing HPMC and $\mathrm{NaCMC}$ increased the release rate of captopril. It was interesting to note that although partial replacement of HPMC by EC reduced the release rate of the drug (ratio of HPMC/EC 2:1), the release rate was increased when the ratio of HPMC/EC was reduced to 1:1. The effects of various surfactants on the release rate of captopril from HPMC/EC (1:1) matrices were also investigated. The results showed that the surfactants did not significantly change the release rate of the drug. Release data were examined kinetically and the ideal kinetic models were estimated for the drug release. The kinetic analysis of drug release data from various formulations showed that incorporation of surfactants in HPMC/EC matrices did not produce a zero-order release pattern.
\end{abstract}

Keywords: captopril, polymers, controlled release, surfactant, release kinetic

*Correspondence, e-mail: a.nokhodchi@kent.ac.uk 
Captopril is freely water-soluble and has an elimination half-life of $1.7 \mathrm{~h}$ after an oral dose (1). It is usually prescribed to patients who are chronically ill and require long-term use for therapeutic benefit. Development of a once daily captopril oral formulation would be a significant advantage for patient compliance accompanied by minimization of the drug side effects as a result of reduction in the drug blood concentration fluctuations, especially in long-term therapy (2).

The release of highly water-soluble medicinal compounds having fast rates of dissolution is of special interest. Matrix tablets have long been used to obtain sustained drug delivery and it was Higuchi (3) who first presented a detailed mathematical analysis of such release. Bomba et al. (4) further developed the mechanisms of release from matrix systems that swell at the tablet periphery to form a gel which acts as a barrier to drug diffusion.

Various studies of the release from matrices in which a surfactant had been incorporated showed a faster release with the addition of surfactant $(5,6)$. According to the importance of captopril sustained release formulation in clinical use, different attempts have been made to design long acting devices for captopril delivery in the form of sustained or controlled release formulations (7-9). The effect of surfactants was not studied in controlled or sustained-release formulations for captopril delivery. Therefore, the present study firstly concerns the release of captopril from hydroxypropylmethylcellulose (HPMC K15M), sodium carboxymethylcellulose (NaCMC), ethylcellulose (EC) and their mixtures matrices and secondly the effect of anionic, cationic, and nonionic surfactants incorporated in an inert, heterogeneous HPMC matrix in order to obtain zero-order release formulations. This study also examines the effect of surfactants on the mechanism of drug release from HPMC-EC matrices.

\section{EXPERIMENTAL}

\section{Materials}

Captopril (Iran Darou, Iran), Methocel K15M (Colorcon, UK), NaCMC (Aqualon, France), ethylcellulose (Merck, Germany), lactose (BDH Chemicals, UK), magnesium stearate (BDH Chemicals), Tween 80 (Merck), Arlacel 60 (BDH Chemicals), sodium lauryl sulphate SLS (BDH Chemicals) and cetytrimethyl ammonium bromide (CTAB) (Merck) were used as obtained.

\section{Preparation of tablets}

Captopril matrices were produced by mixing captopril with HPMC K15M, ethylcellulose, NaCMC or their mixture for a period of $15 \mathrm{~min}$ in a double cone mixer. After completed mixing, magnesium stearate was added and mixed for $2 \mathrm{~min}$. The mixtures were compressed on a 9-mm punch at a pressure of $150 \mathrm{MPa}$ (Table I).

In case of formulations F8 and F9, 25\% and 50\% of HPMC was mixed with drug-lactose (ratio 1:1), respectively, and granulated with distilled water. The moist granules were passed through a sieve (aperture size $1.4 \mathrm{~mm}$ ). The granules were dried in an oven at $60{ }^{\circ} \mathrm{C}$ for a period of $24 \mathrm{~h}$. The dried granules were mixed with the remainder of HPMC 
A. Nokhodchi et al.: Effect of various surfactants and their concentration on controlled release of captopril from polymeric matrices, Acta Pharm. 58 (2008) 151-162.

Table I. Different formulations of captopril matrices and their compositions

\begin{tabular}{cccccccc}
\hline Code & $\begin{array}{c}\text { Lactose } \\
(\mathrm{mg})\end{array}$ & $\begin{array}{c}\text { HPMC } \\
(\mathrm{mg})\end{array}$ & $\begin{array}{c}\text { NaCMC } \\
(\mathrm{mg})\end{array}$ & $\begin{array}{c}\text { EC } \\
(\mathrm{mg})\end{array}$ & $\begin{array}{c}\text { CTAB } \\
(\mathrm{mg})\end{array}$ & $\begin{array}{c}\text { Arlacel 60 } \\
(\mathrm{mg})\end{array}$ & $\begin{array}{c}\text { SLS } \\
(\mathrm{mg})\end{array}$ \\
\hline F1 & - & 50 & - & - & - & - & - \\
F2 & - & 100 & - & - & - & - & - \\
F3 & - & 150 & - & - & - & - & - \\
F4 & - & 125 & 25 & - & - & - & - \\
F5 & - & 100 & 50 & - & - & - & - \\
F6 & 25 & 100 & 25 & - & - & - & - \\
F7b & 50 & 75 & 25 & - & - & - & - \\
F8c & 50 & 75 & 25 & - & - & - & - \\
F9d & 50 & 75 & 25 & - & - & - & - \\
F10 & - & 100 & - & 50 & - & - & - \\
F11 & - & 75 & - & 75 & - & - & - \\
F12 & - & 75 & - & 75 & - & - & $4.5(3 \%)$ \\
F13 & - & 75 & - & 75 & - & - & $9.5(6 \%)$ \\
F14 & - & 75 & - & 75 & - & - & $20.5(12 \%)$ \\
F15 & - & 75 & - & 75 & $4.5(3 \%)$ & - & - \\
F16 & - & 75 & - & 75 & $9.5(6 \%)$ & - & - \\
F17 & - & 75 & - & 75 & $20.5(12 \%)$ & - & - \\
F18 & - & 75 & - & 75 & - & $4.5(3 \%)$ & - \\
F19 & - & 75 & - & 75 & - & $9.5(6 \%)$ & - \\
F20 & - & 75 & - & 75 & - & $20.5(12 \%)$ & - \\
\hline
\end{tabular}

a Amount of captopril in all formulation is $50 \mathrm{mg}$.

b Simple mixture.

c $25 \%$ of HPMC was granulated with water.

d $50 \%$ of HPMC was granulated with water.

and $\mathrm{NaCMC}$ for $10 \mathrm{~min}$. After completed mixing, magnesium stearate was added and mixed for $2 \mathrm{~min}$. The mixtures were compressed on a $9-\mathrm{mm}$ punch at a pressure of 150 MPa (Table I).

A mixture of HPMC and ethylcellulose (1:1) was chosen to investigate the effect of surfactant on the release rate of captopril from matrices (see Table I). Captopril ( $25 \mathrm{~g}$ ) was mixed well with the mixture of HPMC $(75 \mathrm{~g})$ and ethylcellulose $(75 \mathrm{~g})$ for a period of $15 \mathrm{~min}$ in a double cone mixer. Then the mixture was transferred to mortar with pestle and surfactant was added $(3,6$ or $12 \%, \mathrm{~m} / \mathrm{m})$ to the mixture and mixed for an additional period of 15-20 min. After completed mixing, magnesium stearate was added and mixed for $2 \mathrm{~min}$. The mixtures were compressed on a $9-\mathrm{mm}$ punch at a pressure of 150 $\mathrm{MPa}$ (Table I). The amount of captopril was $50 \mathrm{mg}$ in all formulations. 


\section{Dissolution studies}

The USP basket method (10) was used for all in vitro dissolution studies. In this method, distilled water containing $\mathrm{HCl} 0.1 \mathrm{~mol} \mathrm{~L}^{-1}$, which simulated gastric fluid ( $\mathrm{pH} 1.2$ ), and intestinal fluid ( $\mathrm{pH}$ 6.8) containing phosphate buffer without enzyme were used as dissolution media. Phosphate buffer was prepared according to USP (10) from of $0.2 \mathrm{~mol} \mathrm{~L}^{-1}$ monobasic potassium phosphate and $0.2 \mathrm{~mol} \mathrm{~L}^{-1}$ sodium hydroxide. The stirring rate was $100 \pm 2 \mathrm{rpm}$. Matrices were placed in $900 \mathrm{~mL}$ of gastric fluid and maintained at $37 \pm$ $0.1{ }^{\circ} \mathrm{C}$ for $2 \mathrm{~h}$. At appropriate intervals, $5 \mathrm{~mL}$ of samples were taken and filtered through a $0.45-\mu \mathrm{m}$ Millipore filter. The dissolution medium was then replaced by $5 \mathrm{~mL}$ of fresh dissolution fluid to maintain a constant volume. After 2 hours, the dissolution medium $\mathrm{pH}$ was changed from 1.2 to 6.8 using phosphate buffer to simulate intestinal fluid. The samples were then analyzed at 205 and $206 \mathrm{~nm}$ at pH 1.2 and 6.8, respectively, using a UV/Vis spectrophotometer (Shimadzu, Japan) (10). The mean of three determinations was used to calculate the drug release from each formulation.

\section{Release parameters}

To investigate the mode of drug release from matrices, Eq. (1) was applied to interpret the release rate from matrices (11):

$$
Q=K_{1} t^{n}
$$

where $Q$ is the percent of drug released at time $t, K_{1}$ is the constant incorporating structural and geometric characteristics of the release device and $n$ is the release exponent indicative of the mechanism of release. When $n$ approximates 0.5 , a Fickian/diffusion-controlled release is implied, where $0.5<n<1.0$ non-Fickian transport and $n=1$ for zero-order (case II transport). When the value of $n$ approaches 1.0, one may phenomenologically conclude that the release is approaching zero-order.

To compare the effects of polymer or surfactant type or concentration on the drug release, different criteria were used, such as mean dissolution time $(M D T)$ and dissolution efficiency $(D E)$. Mean dissolution time is described below (12):

$$
M D T=\frac{\sum_{j=1}^{n} t \Delta M j}{\sum_{j=1}^{n} t M j}
$$

where $j$ is the sample number, $n$ is the number of dissolution times, $t$ is the time at midpoint between $t$ and $t-1$ (easily calculated with $(t+t-1) / 2$ ) and $\Delta M j$ is the additional amount of drug dissolved between $t$ and $t-1$. Dissolution efficiency $(D E)$ was used as the criterion for comparing the effect of polymer and surfactant concentration on the release rate. The dissolution efficiency $(D E)$ of a pharmaceutical dosage form is defined as the area under the dissolution curve up to a certain time, $t$, expressed as percentage of the 
area of the rectangle described by $100 \%$ dissolution in the same time. $D E$ is described below (13):

$$
D E=\frac{\int_{0}^{T} Y \times d t}{Y_{100} \times T} \times 100 \%
$$

where $Y$ is the percent drug release as the function of time, $t, T$ is the total time of drug release and $Y_{100}$ is $100 \%$ drug release.

\section{Statistical analysis}

All data were statistically analyzed by the analysis of variance or Tukey's multiple comparison test.

\section{RESULTS AND DISCUSSION}

All formulations were relatively robust in terms of friability and hardness (Table II). Table I shows the formulation compositions analyzed in this study. The effect of HPMC $\mathrm{K} 15 \mathrm{M}$ concentration on the release rate of captopril is shown in Fig. 1a. The results showed that an increase in the concentration of HPMC (F1-F3) resulted in a reduction of the captopril release rate. $D E$ and $M D T$ were used to compare the dissolution data. The results of fitting the dissolution data with these dissolution criteria are shown in Table II. $D E$ values are consistent with the dissolution data. For example, the $D E$ value for the tablets containing $50 \mathrm{mg}$ HPMC is $72.7 \%$ whereas this value decreased to 62.2 or $50 \%$ for the tablets containing 100 or $150 \mathrm{mg}$ HPMC, respectively. The ANOVA statistical test showed that the reduction in $D E$ percentage was significant $(p<0.05)$. However, it seems that the amount of HPMC does not change the release pattern. No positive deviation occurred from the curves, indicating that attrition did not contribute to drug release (14).

Simple examination of Fig. 1a shows that as the polymer fraction increased, the dissolution of the drug decreased. However, a prospective formulator would require a more quantitative rationalisation of these trends. The slopes $\left(\% \mathrm{~min}^{-1 / 2}\right)$ of Eq. (1) are given in Table II. When these slopes were plotted as a function of the reciprocal of the HPMC concentration at which they were obtained, a straight line plot was obtained (correlation coefficient 0.999). The general relationship for the line can be expressed by Eq. (4).

$$
R=M(1 / W)+C
$$

where $R$ is the Higuchian release rate $\left(\% \min ^{-1 / 2}\right), M$ is the slope of derived line (\% $\left.\mathrm{min}^{-1 / 2} \mathrm{mg}\right), W$ is the mass of HPMC $(\mathrm{mg}), C$ is the constant $\left(\% \mathrm{~min}^{-1 / 2}\right)$ representing the captopril release rate at a theoretically infinitely high HPMC level.

The derived values of $M$ and $C$ were 756 and 0.364 , respectively. The data mentioned above permit the dissolution rate to be estimated from a limited number of data 



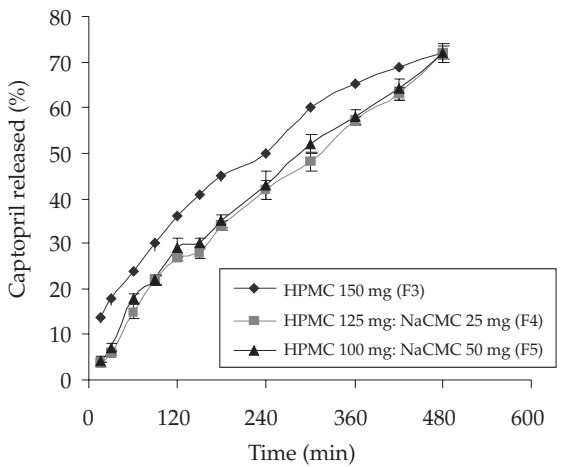

d)

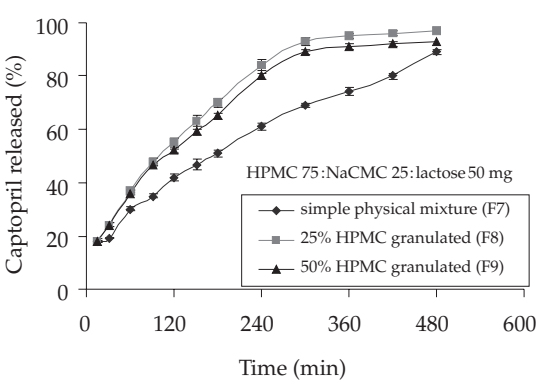

Fig. 1. The effect of various polymers, lactose and granulation technique on the release of captopril from polymeric matrices: a) HPMC $\mathrm{K} 15 \mathrm{M}$; b) NaCMC; c) lactose; d) granulated HPMC; e) ethylcellulose (results are the mean \pm standard deviation of at least 3 runs).

points. Such a relationship was also obtained for promethazine hydrochloride with varying concentrations of HPMC of different viscosity grade (15).

Fig. $1 \mathrm{~b}$ shows the effect of incorporated $\mathrm{NaCMC}$ on the release rate of captopril from HPMC matrices. The results indicate that replacement of HPMC with NaCMC caused a considerable reduction $(p<0.05)$ in drug release (compare release profiles of F3 and F4 in Fig. $1 \mathrm{~b}$ and also $D E$ and $M D T$ in Table II). DE and MDT values significantly changed from $40 \%$ and 178.9 min to $53 \%$ and 144.6 min for F4 and F6 formulations, respectively. However, there was no significant difference between formulations F4 the 
(HPMC/NaCMC ratio was 5:1) and F5 (the HPMC/NaCMC ratio was 2:1). For example, after $4 \mathrm{~h}$, the amounts of drug released from formulations F3, F4 and F5 were 50, 42 and $43 \%$, respectively.

Fig. 1c shows the dissolution characteristics of matrices prepared with different ratios of HPMC/lactose. Addition of lactose led to a significant increase $(p<0.05)$ in the release rate of captopril (compare F4 and F6 in Fig. 1c). An increase in the amount of lactose from 25 (formulation F6) to $50 \mathrm{mg}$ (formulation F7) resulted in an increase in the release rate of captopril (Fig. 1c). For example, after $4 \mathrm{~h}$, the percentages of drug released were 42,57 and $61 \%$ from matrices containing 0,25 and $50 \mathrm{mg}$ lactose, respectively. This could be due to a reduction in the tortuosity of the diffusion path of the drug caused by lactose and/or the gel layer became thinner because of smaller amount of HPMC in these formulations. It was interesting to note that the granulating of HPMC with water had a significant effect on drug release. For instance in Fig. 1d, F7 was a simple mixture of components, in F8 and F9, 25 and 50\% of HPMC was granulated with water and then mixed with other ingredients. The figure shows that when $25 \%$ of granulated HPMC was incorporated into the matrix formulation, the amount of drug released increased from 61 to $84 \%$ after $4 \mathrm{~h}$ (compare F7 and F8). As more granulated HPMC was incorporated, there was no significant increase in the release rate of captopril.

Fig. 1e shows the effect of ethylcellulose on the release rate of captopril from HPMC matrices. Although partial replacement of HPMC by EC increased the release rate of the drug (F3 and F11 in Fig. 1e), when the ratio of HPMC/EC was reduced to 1:1 (F11), the amount of captopril released increased from 52 to $62 \%$. It can be seen that the difference in release profiles of F3, F10 and F11 is more significant at pH 6.8 than it is at pH 1.2.

To investigate the effects of surfactants on the release rate of captopril, HPMC K15M/EC (1:1) was chosen as the inert matrix. The release of captopril from matrices containing different percentages of SLS (formulations F11-F14) was measured. The release rate of captopril from Methocel K15M-EC matrices was generally decreased by the anionic surfactant (Fig. 2a). The rate of drug release slightly decreased as more surfactant was added to the formulation. ANOVA and Tukey's multiple comparison tests showed that the presence of SLS did not cause any significant changes in the amount of drug released from these matrices, with the exception of high SLS concentration $(12 \%)$. The presence of high SLS concentration (12\%) caused a significant decrease in drug release $(p<0.05)$. For instance, the amount of captopril released decreased from 65 to $55 \%$ after $4 \mathrm{~h}$.

As captopril has two $\mathrm{p} K_{\mathrm{a}} \mathrm{s} 3.7$ (weak acid) and 9.8 (very weak acid), the drug will be in cationic form (about 99\%) at $\mathrm{pH} 1.2$ possessing the ability of complex formation with the anionic surfactant SLS. Thus SLS is expected to retard the release rate of captopril at $\mathrm{pH}$ 1.2. The data showed that SLS retarded the release of captopril at $\mathrm{pH}$ 6.8. At higher SLS concentration (12\%), the release rate of captopril was higher than in SLS 6\%, $\mathrm{m} / \mathrm{m}$. At $\mathrm{pH} 6.8$, captopril has a negative charge on the carboxyl group and a positive charge on nitrogen. Therefore, SLS is still able to interact with the cationic group to make a complex. In addition, the retardation effect of SLS could be due to enhanced viscosity of the gel layer surrounding the matrix, which leads to reduction in the release rate of drugs (16). Walderhasug et al. (17) studied the nature of the interaction between SLS and cellulose ethers. They concluded that the anionic surfactant could bind to the non-ionic cellulose to form a strong gel network. Furthermore, complexation and subsequent precipita- 

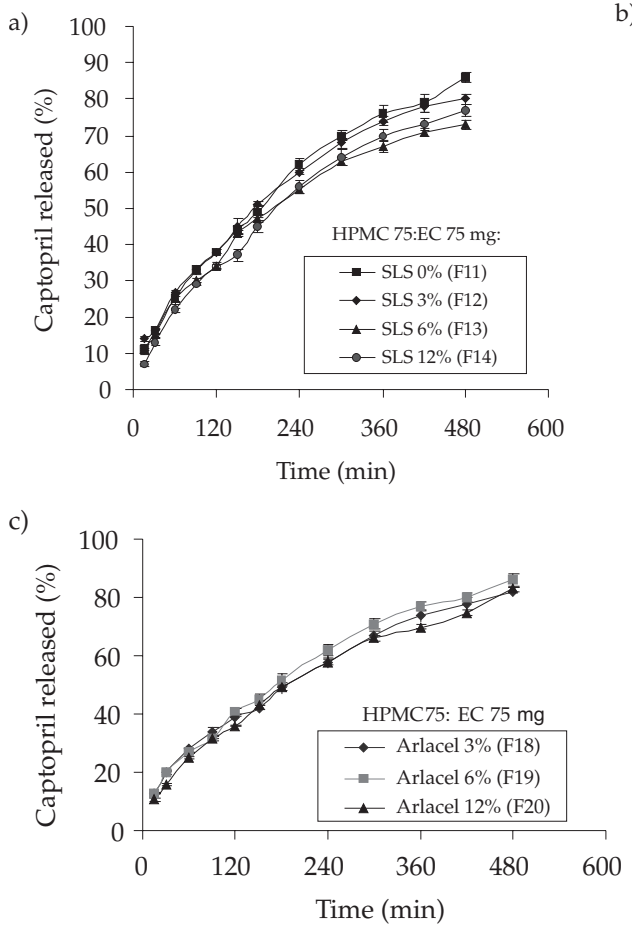

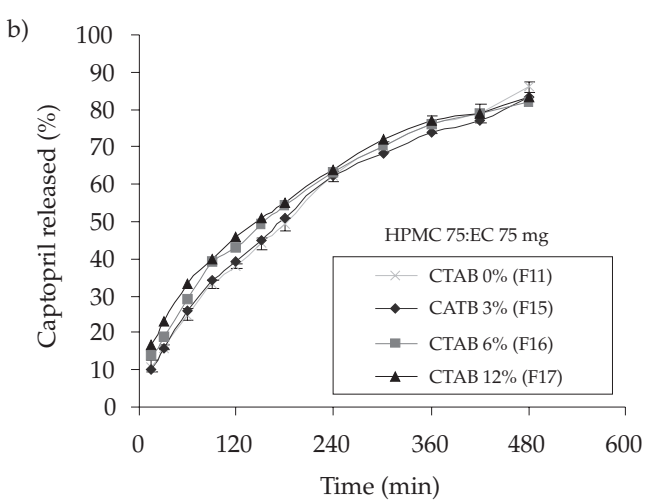

Fig. 2. The effect of different concentrations of various surfactants on the release rate of captopril from polymeric matrices: a) SLS; b) CTAB; c) Arlacel (results are the mean \pm standard deviation of 3 determinations).

tion provide a more tortuous pathway and less porous matrix through which the dissolved medicinal compound must diffuse (18). Daly et al. (19) found that the incorporation of $15 \%$ SLS in modified hydroxypropyl methylcellulose matrices produced a zero-order release of chlorpheniramine maleate. Feely and Davis (20) reported that the release rate of chlorpheniramine maleate from a HPMC matrix was reduced as more SLS was incorporated into the matrix.

The release of captopril from matrices containing CTAB as cationic surfactant $0-12 \%$ $(\mathrm{m} / \mathrm{m})$ (formulations F3, F13-F15) is shown in Fig. 2b. The release of the drug from the matrices was increased by the cationic surfactant $\mathrm{CTAB}$ at $\mathrm{pH} 1.2$. As the concentration of CTAB increased from 0 to $12 \%(\mathrm{~m} / \mathrm{m})$, the amount of the drug released increased from 38 to $45 \%$ after 2 hours. As captopril has a positive charge at $\mathrm{pH}$ 1.2, CTAB is not able to interact with captopril.

The release of captopril from matrices containing 0-12\% $\mathrm{m} / \mathrm{m}$ Arlacel 60 as non-ionic surfactant (formulations F11, F18-F20) is illustrated in Fig. 2c. It can be seen that the release rate was not affected significantly as the concentration of Arlacel 60 was increased from 0 to $12 \%$. Similar results were obtained when $D E$ and $M D T$ were compared for matrices with different concentrations of Arlacel. The results (Table II) showed that the presence of Arlacel in concentrations of $3-12 \%$ had no significant effect on DE and MDT. 
A. Nokhodchi et al: Effect of various surfactants and their concentration on controlled release of captopril from polymeric matrices, Acta Pharm. 58 (2008) 151-162.

Table II. Hardness, $\mathrm{K}_{1}, \mathrm{n}$ and $\mathrm{R}$ based on $\mathrm{Eq}$. (1) for controlled release formulations of captopril

\begin{tabular}{|c|c|c|c|c|c|c|}
\hline $\begin{array}{l}\text { Formulation } \\
\text { code }\end{array}$ & $\begin{array}{l}\text { Hardness } \\
(\mathrm{kg})\end{array}$ & $K_{1}$ & $n$ & $R$ & $D E(\%)^{\mathrm{a}}$ & $\operatorname{MDT}(\min )^{\mathrm{a}}$ \\
\hline F1 & $10 \pm 2$ & 9.50 & 0.38 & 0.966 & $72.7 \pm 5.2$ & $84.2 \pm 9.8$ \\
\hline F2 & $12 \pm 2$ & 5.38 & 0.46 & 0.994 & $62.2 \pm 2.4$ & $120.2 \pm 12.1$ \\
\hline F3 & $11 \pm 3$ & 3.14 & 0.52 & 0.988 & $50.0 \pm 2.1$ & $133.5 \pm 11.9$ \\
\hline F4 & $9 \pm 2$ & 0.41 & 0.85 & 0.985 & $40.1 \pm 2.4$ & $178.9 \pm 13.5$ \\
\hline F5 & $11 \pm 2$ & 0.49 & 0.82 & 0.983 & $41.6 \pm 2.5$ & $172.2 \pm 12.3$ \\
\hline F6 & $10 \pm 3$ & 3.65 & 0.50 & 0.994 & $53.0 \pm 3.5$ & $144.6 \pm 13.4$ \\
\hline F7 & $12 \pm 3$ & 4.17 & 0.49 & 0.988 & $56.9 \pm 4.2$ & $141.8 \pm 8.6$ \\
\hline F8 & $14 \pm 2$ & 3.83 & 0.56 & 0.995 & $73.0 \pm 5.2$ & $115.3 \pm 12.0$ \\
\hline F9 & $15 \pm 3$ & 4.07 & 0.54 & 0.997 & $69.7 \pm 4.0$ & $116.6 \pm 8.9$ \\
\hline F10 & $9 \pm 1$ & 1.69 & 0.62 & 0.983 & $52.1 \pm 2.1$ & $163.2 \pm 14.2$ \\
\hline F11 & $11 \pm 2$ & 2.27 & 0.59 & 0.993 & $55.5 \pm 2.9$ & $145.1 \pm 11.2$ \\
\hline F12 & $12 \pm 1$ & 2.91 & 0.55 & 0.994 & $54.9 \pm 4.0$ & $142.9 \pm 10.8$ \\
\hline F13 & $13 \pm 2$ & 2.38 & 0.57 & 0.997 & $50.3 \pm 2.9$ & $141.0 \pm 10.6$ \\
\hline F14 & $9 \pm 2$ & 1.46 & 0.66 & 0.993 & $50.4 \pm 3.5$ & $150.5 \pm 11.0$ \\
\hline F15 & $11 \pm 1$ & 2.13 & 0.60 & 0.991 & $55.2 \pm 2.1$ & $138.5 \pm 11.3$ \\
\hline F16 & $12 \pm 2$ & 3.30 & 0.53 & 0.995 & $57.5 \pm 1.9$ & $131.7 \pm 8.9$ \\
\hline F17 & $11 \pm 2$ & 4.90 & 0.46 & 0.998 & $59.1 \pm 3.5$ & $122.6 \pm 8.7$ \\
\hline F18 & $9 \pm 3$ & 3.11 & 0.53 & 0.998 & $54.6 \pm 2.9$ & $145.4 \pm 11.2$ \\
\hline F19 & $9 \pm 3$ & 2.96 & 0.55 & 0.995 & $56.9 \pm 3.1$ & $140.8 \pm 11.9$ \\
\hline F20 & $10 \pm 2$ & 2.21 & 0.59 & 0.998 & $53.0 \pm 2.6$ & $144.0 \pm 9.9$ \\
\hline
\end{tabular}

a Mean $\pm \mathrm{SD}, n=3$.

It can be concluded for these surfactants that wetting does not play a significant role in the dissolution process and that the minor acceleration or retardation observed with the incorporation of CTAB and SLS might be due to the surfactant dissolving and forming pores/channels, which increases the effective surface area by a method other than wetting.

Two possible mechanisms have been postulated as to why surfactants increase the rate of drug release from matrix formulations $(21,22)$. Firstly, it is possible that the surfactant lowers the interfacial tension between the product and the dissolution fluid; secondly, it is possible that the surfactant acts as a wicking agent, causing the fluid to enter the dosage form; the surfactant may then dissolve and form pores (or other disruptions) from which the drug release may be affected (21). The same results were reported on the effect of surfactants on the dissolution profiles of flurbiprofen (22). Efentakis et al. (18) showed that in most cases, wetting plays a small role in aiding dissolution. They concluded that the major mechanism by which surfactants increase the dissolution rate is the 
formation of pores to aid the access of the dissolution fluid and egress of the dissolved drug. It is also possible that the presence of the relatively concentrated surfactant solution in the wetted tablet would reduce interparticle adhesion and thereby enhance the drug release rate as a result of increased disintegration.

As captopril is a highly soluble drug, the release will be predominantly controlled by diffusion. The release kinetics from matrices composed of varying ratios of polymer(s) and surfactants were analyzed using Eq. (1); the results are shown in Table II. It can be observed that increasing HPMC concentration leads to higher $n$ values. It is clearly seen that the $n$ values for matrices containing HPMC or the mixtures of HPMC and lactose are around 0.5 because of the high solubility of captopril in dissolution media, indicating the diffusion release mechanism. Table II shows that incorporating NaCMC in HPMC matrices leads to a significant increase in $n$ values. This indicates that the presence of $\mathrm{NaCMC}$ in HPMC matrices increases the contribution of erosion in the captopril release.

The presence of higher concentration $(12 \%, \mathrm{~m} / \mathrm{m})$ of the anionic surfactant (SLS) slightly increased the $n$ value. The values of $n$ were between 0.55 and 0.66 for matrices containing different concentrations of SLS, ranging from $0-12 \%(\mathrm{~m} / \mathrm{m})$. In other words, there is a slightly higher contribution of diffusion in the presence of 3 or $6 \%$ SLS compared to with the matrices with $12 \%$ surfactant. A similar result was obtained for matrices containing Arlacel 60, in which the contribution of diffusion was predominant at lower concentration of surfactants ( 3 and $6 \%, \mathrm{~m} / \mathrm{m}$ ). Table II also shows that an increase in the concentration of CTAB results in a reduction in the value of $n$. For example, when the concentration of CTAB is increased from 3 to 6 and $12 \%(\mathrm{~m} / \mathrm{m})$, the value of $n$ was reduced from 0.60 to 0.53 and 0.46 , respectively. This shows that a low concentration of CTAB has no significant effect on the mechanism of release, whereas the contribution of diffusion increases with higher $\mathrm{CTAB}$ concentrations compared to with matrices without the surfactant (F11).

\section{CONCLUSIONS}

The present work has showed that surfactants can be used to control the release rate of captopril from HPMC-EC matrices. However, they are not able to produce the zero-order release pattern for captopril matrices. The magnitude of the increase or decrease of release rate remarkably depends on the type of surfactant and on concentration. The results also show that the surfactants are able to change the mechanism of captopril release from the matrices. The principal mechanism by which surfactants retard drug release from HPMC-EC matrices is the drug/surfactant ionic interaction. 


\section{REFERENCES}

1. K. L. Duchin, S. M. Singhavi, D. A. Willard, B. H. Migdalof and D. N. Mckinstry, Captopril kinetics, Clin. Pharmacol. Therr. 31 (1982) 452-458.

2. Y. Seta, F. Higuchi, Y. Kawahara, K. Nishimura and R. Okada, Design and preparation of captopril sustained release dosage forms and their biopharmaceutical properties, Int. J. Pharm. 41 (1988) 245-254; DOI: 10.1016/0378-5173 (88) 90201-3.

3. T. Higuchi, Mechanism of sustained-action medication. Theoretical analysis of the rate of release of solid drugs dispersed in solid matrices, J. Pharm. Sci. 52 (1963) 1145-1149.

4. M. Bomba, F. Puisieux, J. P. Marty and J. T. Carstensen, Release mechanisms in gel forming sustained release preparations, Int. J. Pharm. 2 (1979) 307-315; DOI: 10.1016/0378-5173(79) 90037-1.

5. A. Nokhodchi, P. Khaseh, T. Ghafourian and M. R. Siahi-Shadbad, The role of various surfactants and fillers in controlling the release rate of theophylline from HPMC matrices, STP Pharm. Sci. 9 (1999) 555-560.

6. A. Nokhodchi, S. Norouzi-Sani, M. R. Siahi-Shadbad, F. Lotfipoor and M. Saeedi, The effect of various surfactants on the release rate of propranolol hydrochloride from hydroxypropylmethylcellulose-eudragit matrices, Eur. J. Pharm. Biopharm. 54 (2002) 349-356; DOI: 10.1016/S0939$-6411(02) 00120-0$.

7. Y. Seta, F. Higuchi, T. Otsuka, Y. Kawahara, K. Nishimura, R. Okada and H. Koike, Preparation and pharmacological evaluation of captopril sustained-release dosage forms using oily semisolid matrix, Int. J. Pharm. 41 (1988) 255-262; DOI: 10.1016/0378-5173(88)90202-5.

8. Y. Seta, T. Otsuka, H. Tokiwa, H. Naganuma, Y. Kawahara, K. Nishimura and R. Okada, Design of captopril sustained-release preparation with oily semisolid matrix intended for use in human subjects, Int. J. Pharm. 41 (1988) 263-269; DOI: 10.1016/0378-5173(88)90203-7.

9. R. S. Matharu and N. M. Singhavi, Novel drug delivery system for captopril, Drug Dev. Ind. Pharm. 18 (1992) 1567-1574.

10. USP Pharmacopoeia 26, National Formulary 21, USP Convention, Rockville, 2003, pp. 320.

11. P. L. Ritger and N. A. Peppas, A simple equation for describing of solute release II. Fickian and anomalous release from swellable devices, J. Control. Rel. 5 (1987) 37-42; DOI: 10.1016/016836591(87)90035-6.

12. K. A. Khan, Concept of dissolution efficiency, J. Pharm. Sci. 271 (1975) 48-49.

13. F. Podczeck, Comparison of in vitro dissolution profiles by calculating mean dissolution time (MDT), or mean residence time (MRT), Int. J. Pharm. 97 (1993) 93-100; DOI: 10.1016/0378-5173 (93)90129-4.

14. H. Lapidus and N. G. Lordi, Drug release from compressed hydrophilic matrices, J. Pharm. Sci. 57 (1968) 1292-1301.

15. J. L. Ford, M. H. Rubinstein and J. E. Hogan, Dissolution of a poorly water soluble drug, indomethacin, from hydroxypropylmethylcellulose controlled release tablets, J. Pharm. Pharmacol. 37 (Suppl.) (1985) 33P.

16. J. Akbari, M. Adrangui, J. Farid, M. R. Siahi-Shadbad, M. Saeeidi and A. Nokhodchi, The effects of various factors on the release rate of a poorly soluble drug (Carbamazepine) from hydroxypropylmethylcellulose matrices, STP Pharm. Sci. 10 (2000) 473-478.

17. H. M. Walderhsaug, B. Nystrom, F. K. Hansen and B. Lindman, Interaction of anionic surfactants with a non-ionic cellulose ether in solution and in the gel state by pulsed field gradients NMR, J. Phys. Chem. 99 (1995) 4672-4678.

18. M. Efentakis, H. Al-Hmoud and N. H. Choulis, Effects of additives on flurbiprofen controlled release preparation, Acta Pharm. Technol. 36 (1990) 237-239. 
19. P. B. Daly, S. S. Davis and J. W. Kennerley, The effect of anionic surfactants on the release of chlorpheniramine from a polymer matrix tablet, Int. J. Pharm. 18 (1984) 201-205; DOI: 10.1016/ 0378-5173(84)90120-0.

20. L. C. Feely and S. S. Davis, Influence of surfactants on drug release from hydroxypropylmethylcellulose, Int. J. Pharm. 41 (1988) 83-90; DOI: 10.1016/0378-5173(88)90139-1.

21. A. Dakkuri, H. G. Schroeder and P. P. Deluca, Sustained release from inert wax matrices. II. Effect of surfactants on tripelennamin hydrochloride release, J. Pharm. Sci. 67 (1978) 355-357.

22. S. J. Desai, A. P. Simonelli and W. I. Higuchi, Investigation of factors influencing the release of solid drug dispersed in inert matrices, J. Pharm. Sci. 54 (1965) 1459-1464.

\section{$S A \check{Z} E T A K$}

\section{Utjecaj različitih površinski aktivnih tvari i njihovih koncentracija na kontrolirano oslobađanje kaptoprila iz polimernih matriksa}

ALI NOKHODCHI, DAVOUD HASSAN-ZADEH, FARNAZ MONAJJEM-ZADEH i NITA TAGHI-ZADEH

Postoje različite metode formuliranja vodotopljivih lijekova u dozirane ljekovite oblike s polaganim oslobađanjem. Jedan od načina postizanja kontroliranog otpuštanja, a prema tome i produljenog učinka je upotreba hidrofilnih i lipofilnih polimera. U ovom radu proučavan je utjecaj različitih polimera poput hidroksipropil metilceluloze (HPMC), etilceluloze (EC) i natrijeve soli karboksimetilceluloze (NaCMC) i površinski aktivnih tvari (natrijevog lauril-sulfata, cetiltrimetilamonijevog bromida i Arlacela 60) na oslobađanje kaptoprila. Rezultati pokazuju da povećanje količine HPMC K15M ima za posljedicu smanjenje oslobađanja kaptoprila iz matriksa. Ako se HPMC djelomično zamijeni s $\mathrm{NaCMC}$ (omjer HPMC/NaCMC 5:1), oslobađanje ljekovite tvari značajno se smanjuje. Međutim, nema značajne razlike $u$ oslobađanju kaptoprila iz matriksa s omjerom HPMC / NaCMC 5:1 i 2:1. Prisutnost laktoze u matriksu koji sadrži HPMC i NaCMC povećalo je oslobađanje kaptoprila. Iako djelomična zamjena HPMC s EC smanjuje oslobađanje ljekovite tvari (omjer HPMC/EC 2:1), oslobađanje se povećava uz omjer HPMC/EC 1:1. Nadalje, ispitivan je utjecaj površinski aktivnih tvari na oslobađanje kaptoprila iz matriksa u kojima je omjer HPMC/EC (1:1). Može se zaključiti da površinski aktivne tvari ne utječu značajno na oslobađanje ljekovite tvari. U sklopu istraživanja određen je i kinetički model oslobađanja kaptoprila. Analiza kinetičkih podataka ukazuje da dodatak površinski aktivnih tvari u HPMC/EC matrikse ne slijedi kinetiku nultog reda.

Ključne riječi: kaptopril, polimeri, kontrolirano oslobađanje, površinski aktivna tvar, kinetika oslobađanja

Medway School of Pharmacy, The University of Kent and Greenwich, Central Ave., Chatham Maritime ME4 4TB, Kent, UK

Drug Applied Research Center and Faculty of Pharmacy, Tabriz University of Medical Sciences, Tabriz Iran 